\title{
Foreign actors and intellectual property protection regulations in developing countries
}

\author{
Kristin Brandl ${ }^{1}$, \\ Izzet Darendeli ${ }^{2}$ and \\ Ram Mudambi ${ }^{3}$ \\ ${ }^{1}$ Gustavson School of Business, University of \\ Victoria, Victoria, BC, Canada; ${ }^{2}$ California State \\ University - East Bay, Hayward, CA, USA; ${ }^{3}$ Fox \\ School of Business, Temple University, \\ Philadelphia, PA 19122, USA

\section{Correspondence:} \\ R Mudambi, Fox School of Business, Temple \\ University, Philadelphia, PA 19122, USA. \\ Tel: +1215-204-1692; \\ Fax: +1 215-204-8029; \\ e-mail: ram.mudambi@temple.edu
}

Authors are listed in alphabetical order. All authors contributed equally to this work.

Received: 23 November 2016

Revised: 1 May 2018

Accepted: 26 May 2018

Online publication date: 14 August 2018

\begin{abstract}
International agreements and institutions affect innovation in developing countries. We analyze the impact of advanced country multinational enterprises (AMNEs) and supranational organizations on the regulatory adoption of global intellectual property protection standards. In particular, we investigate 60 developing countries that signed the Trade-relate Aspects of Intellectual Property Rights (TRIPS) agreement of the World Trade Organization in 1994. Our empirical findings show that a greater involvement of AMNEs in the domestic innovation systems of developing countries results in more stringent TRIPS adoption and convergence to advanced country IP protection standards. This relationship is positively moderated by country dependency on supranational organizations such as the International Monetary Fund. This analysis contributes to the literature on institutional change and institutional voids. It provides insights into the influence of external actors on the underlying change processes.
\end{abstract}

Journal of International Business Studies (2019) 50, 826-846. https://doi.org/10.1057/s41267-018-0172-6

Keywords: intellectual property protection; innovation system; institutional change theory; institutional voids; developing countries

\section{INTRODUCTION}

Advanced countries have comparatively well-functioning institutions, formal and informal (North, 1990), with legal systems, regulations, conventions, and customs (Coriat \& Weinstein, 2002; Scott, 2013) that facilitate the protection of intellectual property (IP). Developing countries, on the other hand, struggle with institutions as they are either nonexistent or do not work well (Rodrik, 2000). These situations have been characterized as 'institutional voids' (Khanna \& Palepu, 1997) and in the realm of IP, the safeguards in developing countries significantly lag those in advanced countries (Yang \& Sonmez, 2013). However, initiating change in developing countries is particularly challenging since their institutional environments have typically evolved to benefit the extant elites, which are therefore biased toward maintaining the status quo (Acemoglu \& Robinson, 2000).

Moreover, while there is unanimous agreement that catch-up is a fundamental requisite of economic development (Abramovitz, 
1986), there have been conflicting arguments with regard to the IP protection approaches that accelerate this process. Some researchers (e.g., Delgado, Kyle, \& McGahan, 2013) emphasize the need for strong IP protection standards in order to attract advanced country multinational enterprises (AMNEs). Others argue that strong IP protection could be detrimental to domestic firm growth (Helpman, 1993), depressing the innovation capabilities of local organizations and harming the country's innovation system in the long run. Consequently, foreign and domestic firms have opposing preferences with regard to IP protection levels (Stigler, 1971).

Furthermore, external pressures from supranational organizations impact developing countries more significantly than developed countries (Biermann, 2002), though their influences are often less obvious in the former (Lemola, 2002). These overarching effects of supranational organizations are likely to percolate down and influence actors that are part of the countries' innovation systems, such as AMNEs.

Given these conflicting arguments, it is difficult for academics as well as for policymakers, to identify IP protection standards that support the development of domestic innovation systems and the pressures on the development process of institutional environments in developing countries as they attempt to overcome institutional voids. Thus, we study the influence of advanced country MNEs and supranational organizations on the regulatory strengthening of developing country IP protection standards to adapt to global institutional environment standards.

We analyze the regulatory adoption by developing countries of the 1994 Trade-Related Aspects of Intellectual Property Rights (TRIPS) agreement of the World Trade Organization (WTO). Many developing countries that signed the TRIPS agreement lacked minimum IP protection standards in 1994 and had to upgrade their institutional environment. These upgrading paths were often costly and complex. For example, the higher prices for royalty payments charged by developed countries, fees, and penalties, etc., ranged at around $\$ 20$ billion in 2015; in addition, the legal, administrative, and enforcement infrastructure costs were estimated in the range of $\$ 800,000$ for many medium-sized countries (McCalman, 2001; Deere, 2008). However, there was considerable variability in these estimated costs across countries, as the WTO allowed various flexibilities, such as a transition period and/or the possibility to amend the original TRIPS text (McCalman, 2001), resulting in differing adoption paces and stringencies in reaching required TRIPS standards (Deere, 2008).

We ground our theoretical arguments in institutional theory that investigates the influence of actors (e.g., MNEs from advanced economies and supranational organizations) on government decision-making and policies (Bonardi, Hillman, \& Keim, 2005; Kostova, Roth, \& Dacin, 2008). These involve the interaction of multiple actors and their political strategies, lobbying activities, and interconnections within and across country borders (Suchman, 1995).

Our empirical results are based on the full set of 60 developing countries that signed the TRIPS agreement. We find that when multinational enterprises from advanced economies (AMNEs) have a dominant presence in a country's innovation system, accession to full compliance with TRIPS is fast and without many alterations to the original regulations, implying a stringent compliance to the original TRIPS text. Further, the influence of AMNEs for fast and stringent TRIPS implementation is stronger in countries that have a high dependency on supranational organizations, such as the International Monetary Fund (IMF). Thus, AMNEs push developing countries to reach the high IP protection standards prevalent in advanced countries.

Our inquiry is timely and important for several reasons. First, there are few studies that have investigated the changing standards of IP protection in developing countries and particularly the influence of actors and interest groups in this context (Park, 2008; Yang \& Sonmez, 2013). This is especially significant in light of the institutional voids in developing countries. A recent special issue in the Journal of International Business Studies (Doh, Rodrigues, Saka-Helmhout \& Makhija, 2017) on institutional voids emphasizes the need for further research on the topic. We contribute to this literature with insights into the actors that influence developing countries' regulatory adoption of formal institutional arrangements mirroring those in advanced countries. More specifically, we contribute to the academic literature with the finding that factors external to the country impact domestic decision-making with regard to IP protection.

Second, there is a dearth of longitudinal studies that investigate institutional change and the underlying factors that affect these trajectories (McGaughey, Kumaraswamy, \& Liesch, 2016). We 
address this research gap with detailed analyses of the influence of foreign MNEs and supranational organizations on the pace of movement toward global IP protection standards in regimes with institutional plasticity.

The article is organized as follows. We begin by discussing our theoretical framework and developing our research hypotheses. In the subsequent sections, we outline our research methods and present the findings of our empirical analysis. Finally, we discuss our results and the associated implications, before concluding the article with suggestions for future research.

\section{THEORETICAL FOUNDATION AND BACKGROUND}

\section{Institutional Change and Institutional Voids}

Institutional theory describes institutional change as a process that transforms established norms or conditions (North, 1990; 2005). It is influenced by factors internal to the country as well as external factors. These factors include development levels (Park, 2008), income levels (Marron \& Steel, 2000), government regulations (Li \& Resnick, 2003), trade activities (Yang \& Sonmez, 2013) and access to regional blocs like the European Union (Way \& Levitsky, 2007). While we focus on formal institutions, such as policies, rules, and regulations, we acknowledge that informal institutions, such as habits, norms, and customs (North, 1990) are also important factors influencing institutional change.

Governments play a crucial role in designing and facilitating the ecosystems that enable efficient flows of technology and information among people, firms, and universities in a country's innovation system (Nelson, 1993). They form the 'rules of the game' that all other actors in the business environment take as given, i.e., they act as the Stackelberg leader in a strategic sense (Mudambi, 1991). The neo-institutionalism and evolutionary economics literatures (Nelson \& Winter, 1982; Scott, 2013) posit that all organizations operate and create routines within an open environment of competing institutions, not just governments. However, the role of non-state actors in influencing innovation policy is often downplayed in the mainstream literature (Coriat \& Weinstein, 2002).

While this could be a realistic assumption during periods of institutional stasis, it becomes unrealistic during periods of institutional change.
Governments often have limited and imperfect information (Coriat \& Weinstein, 2002), leading them to undervalue the commercial importance of innovation (Paraskevopoulou, 2012), or struggle with complexity of international environments (Patriotta, Gond, \& Schultz, 2011). Thus, interests, incentives, and power dynamics of different highly interconnected actors within the institutional environment (Fiori, 2002) shape institutions, based on their timing (when), their objectives (why), and their approach (how).

'When': According to the policy life cycle perspective (see Baron, 1995; Hillman, Keim \& Schuler, 2004), non-governmental organizations (NGOs) or public organizations are more vocal in the early stages of public policy creation, where issues are identified and interest groups formed. In these early stages, firms engage in constituency building and information strategies (Hillman \& Hitt, 1999) to facilitate information campaigns and public image advertising with the aim of shaping public opinions. The legislative and enforcement stages are the later stages of the policy life cycle, and these are the focus of this study. In these later stages, firms allocate their resources to political action-based strategies such as lobbying, coalitions, or direct connections (Hillman \& Hitt, 1999). In advanced and pluralist countries, NGOs and public organizations are sometimes still active during the legislative and enforcement stages. However, in countries with institutional voids and underdeveloped pluralist political settings, they often have few opportunities to exert influence on the specific legislative and enforcement decisions of governments (Darendeli \& Hill, 2016).

'Why' actors influence institutional change is strongly connected to each actor's objectives and strategies. In the context of innovation, there are significant motivational differences in the forprofit and not-for-profit sector. Private sector actors focus on commercial innovations that can lead to competitive advantages and these stem from applied research. Public sector actors, and universities in particular, focus on knowledge for its own sake, and that arises from basic research (Choudhury \& Khanna, 2014: Motohashi, 2005). Hence, the private sector is incentivized to steer the opinion of the public sector toward institutional change that allows maximizing financial returns on innovation; the public sector aims to create the optimal institutional environment to support these activities and the country's economic development. 
'How' actors influence the institutional change process is dependent on the condition of the institutional environment within a country. In a developing country context, the evidence of institutional voids (Khanna \& Palepu, 1997) and the continued flux of formal and informal institutions offers a variety of channels to influence change (Kostova et al., 2008). Institutional voids inhibit the mechanisms that allow buyers and sellers in a market to come together (Khanna \& Palepu, 1997) and increase transaction costs for all actors.

Firms require capabilities and resources to overcome or fill institutional voids, for example by overcoming the lack of a functioning infrastructure with their own infrastructure-enhancing activities (Cuervo-Cazurra \& Dau, 2009; Darendeli \& Hill, 2016). In this context, foreign firms may have advantages: although they sometimes face liabilities of foreignness (Zaheer, 1995) and outsidership (Cantwell \& Mudambi, 2011; Johanson \& Vahlne, 2009), they have more capital on hand to do so (Hoskisson, Eden, Lau, \& Wright, 2000). Thus, a diversity of actors with distinctly different objectives are interested in influencing change in the institutional environment of a developing country along the three dimensions of timing (when), objectives (why), and modalities (how) (Cantwell, Dunning, \& Lundan, 2010; Ramamurti, 2005).

\section{TRIPS Adoption in Developing Countries}

Advanced countries' institutions have ensured high IP protection standards since the Paris Convention of 1883. However, it has been argued that these high standards arose in response to domestic players' stocks of IP (Botoy, 2004). For instance, in the nineteenth century, US firms were the leading violators of international IP rights, regularly infringing on the knowledge assets of European firms (Peng, Ahlstrom, Carraher \& Shi, 2017). Over time, with US firms' rising stocks of IP, the establishment of the World Intellectual Property Organization (WIPO) in 1967, and the introduction of the Bayh-Dole Act/Patent and Trademark Law Amendments Act in 1980 led to the US IP regime steadily becoming more stringent and formalized (Maskus, 2000).

Developing countries, on the other hand, predominantly transitioned to high IP protection standards only after becoming signatories to agreements from global supranational organizations that require high IP protection standards, such as TRIPS (Li, 2008). The agreement required signatories to enact and enforce rules and regulations for the protection of IP that converged to the high levels of security seen in advanced countries (Taubman, Wager, \& Watal, 2012). At the time TRIPS was signed, almost none of the sixty developing country signatories (with the exception of South Korea) had the required formal institutions of IP regulation, the level of IP protection standards, and the required enforcement mechanisms in place $(\mathrm{Li}$, 2008).

As a result of pre-TRIPS negotiations, the sixty developing countries were provided with two main flexibilities to reach the required TRIPS standards. First, countries were given leeway to adjust their internal systems toward compliance. The signatory countries were allowed a 10 -year transition period, which permitted them to gradually increase their IP protection standards. As a result, some countries ratified the agreement and made it a part of their national IP legislation within one year, others waited for five years, and some even waited until the end of the 10-year transition period to ratify the agreement (Deere, 2008).

Second, countries were allowed to modify TRIPS standards to make them more applicable to their own context, based on local regulatory needs (Deere, 2008; Li, 2008). While these amendments are an alternative and additional way for developing countries to comply with regulations, the change of original TRIPS text is time consuming and costly. For example, amendments require costly consultancy services, i.e., supported by policy research, drafting of new legislations, agency re-organization, and additional training of staff in relevant agencies (Lybbert, 2002). Moreover, the amended TRIPS texts were less stringent in comparison with nonamended TRIPS text.

The decision of developing countries to ratify TRIPS is based on two factors, time (whether to ratify rapidly or delay ratification, perhaps up to the full ten-year period) and stringency (whether to accept the strict TRIPS text as given or request modifications). Due to the vast variety of flexibilities, a considerable amount of diversity in TRIPS compliance and implementation trajectories of developing countries is evident (Yang \& Sonmez, 2013). For example, India incrementally changed its domestic IP standards and utilized the full 10-year transition period while Brazil and Turkey implemented TRIPS IP regulations immediately. Some countries, such as Venezuela and China, introduced amendments to the original TRIPS text, while others, such as Argentina and 
Indonesia, used original TRIPS text (Taubman et al., 2012).

\section{HYPOTHESIS DEVELOPMENT}

Actors seek to influence the change of formal institutions to promote their own interests (Stigler, 1971). Geels (2014) categorizes these actors into internal actors, external actors, and facilitators and argues that they differ systematically in terms of their power to discipline and shape regimes or rules. Using this typology, we include actors from each category in our analysis: country internal actors such as domestic firms or local governments, external actors, such as AMNEs that operate in the domestic innovation system (Narula, 2003), and finally, facilitators, such as supranational organizations.

We disregard other actors in innovation systems such as (local and foreign) NGOs and universities, for two reasons. First, as noted in 'why' actors influence institutional change, for-profit and notfor-profit organizations are driven by different motivations (Motohashi, 2005). Second, our model focuses on the enforcement and legislation stage of the policy life cycle (Hillman et al., 2004), 'when' these other actors are less active. Consequently, we focus our attention on AMNEs as external actors and on supranational organizations as facilitators and study their impact on the countries innovation system. We illustrate these relationships in Figure 1.

\section{The Influence of AMNEs on Regulatory Adoption} Operationalizing Geels' (2014) taxonomy, we consider domestic firms and AMNEs, which conduct $R \& D$ within innovation systems of developing countries, as the two central actors that exercise power to shape institutional environments in these countries. The firms affect local institutional developments by informing, guiding, and engaging in negotiations with governments to influence policies, laws, and regulations (Hillman \& Hitt, 1999), and outline 'how' actors influence institutional

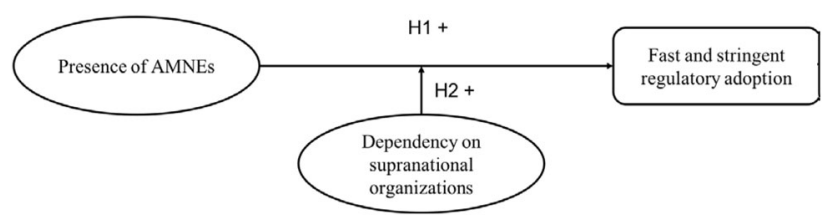

Figure 1 AMNE influence on the estimates of regulatory adoption. change. They engage in strategies to shape institutional environments (Oliver, 1992) through lobbying during different policy life cycle stages (Bonardi et al., 2005). Both types of firms exert this power, but have different mechanisms to do so. Domestic firms often have the advantage of being insiders in the system, which especially helps when overcoming institutional voids (Khanna \& Palepu, 1997). AMNEs may struggle with the liability of foreignness (Zaheer, 1995), the additional risks and uncertainties associated with internationalization (Liesch, Welch, \& Buckley, 2011), and the possibility that the local government may be biased in favor of domestic firms (Rugman \& Verbeke, 2000).

However, AMNEs have equal interests in influencing the formal institutional environment and in shaping it, considerations that link to transaction cost economics and internalization theory (Buckley \& Casson, 1976; Williamson, 1979). Transaction costs influence the financing of international operations (Mudambi, 1998). They depend on the institutional environment and the firm's ability to cope with and influence it when internationalizing (Williamson, 1979). This is accentuated in developing countries due to high enforcement and measurement costs (North, 1990). Beyond cost considerations, AMNEs' integration into the local business environment facilitates their business operations (Verbeke, 2003; Verbeke \& Kano, 2016), especially in developing country contexts (Kano \& Verbeke, 2015).

These influences are heavily dependent on firms' bounded rationalities and reliabilities, as their relationship with policymaking governments is influenced by opportunistic behaviors, commitments and practices, coordination activities, and management mechanisms (Kano \& Verbeke, 2015; Verbeke \& Greidanus, 2009). Thus, the influence of these firms on policymaking and institutional environments is strongly dependent on a range of firm-specific factors, which also distinguish domestic firms from AMNEs.

This distinction between domestic firms and AMNEs is reflected in their contrasting preferred institutional environments, in particular with regard to innovation and IP protection standards. Domestic firms are aware that AMNEs present both opportunities and threats; they are sources of learning and knowledge spillovers (Sanna-Randaccio \& Veugelers, 2007), but they are also significant market competitors. Knowledge spillovers from AMNEs allow 'raising the level of knowledge upon which new innovations can be based' 
(Branstetter, 2001, p. 54) in an innovation system. Thus, knowledge from AMNEs, whether external or developed within the country, 'spills over' into the domestic innovation system (Mudambi, 2008). This knowledge is beneficial for domestic firms, if they have absorptive capacities to recognize the knowledge, internalize it and use it for their own purposes (Blomström \& Kokko, 1998). However, firms from developing countries often struggle to use this knowledge for novel innovation (Li, 2008) and often continue focusing on imitation activities (Awate, Larsen, \& Mudambi, 2012) or cost innovation (Williamson, 2010). Thus, imitation activities and reverse engineering were usually dominant in these countries (Samuelson \& Scotchmer, 2002). Some have argued that technology regimes in developing countries are moving toward increased novelty, including frugal innovation (Zeschky, Widenmayer, \& Gassmann, 2011) and innovations triggered by their unique market conditions (see an example in McGaughey, Liesch, \& Poulson, 2000).

Strong IP protection standards and reverse engineering are difficult to align and thus there is considerable evidence that domestic firms lobby against the implementation of strong IP protection standards (Peng et al., 2017). The slow adoption to stringent IP protection standards as well as loose implementation helps domestic firms to catch-up through sourcing knowledge and collaborating during a period of transition and consolidation (Kumaraswamy, Mudambi, Saranga, \& Tripathy, 2012). Thus, our baseline argument is that developing countries with local innovative activities prefer slower and less stringent adoption of TRIPS IP protection standards.

In contrast, AMNEs are very protective of their IP, innovations and technologies (Hennart, 2009) and prefer strong IP protection standards. Weak IP protection deters them from pursuing valuable competence-creating activities locally (Cantwell \& Mudambi, 2005). Moreover, high IP protection standards can lead to more knowledge spillovers and technology transfers within AMNEs, which also enhance innovation outputs (Branstetter, Fisman, \& Foley, 2006). Thus, AMNEs benefit from and prefer higher IP protection standards and stringent implementation mechanisms. This implies that AMNEs are incented to participate in and influence institutional change in countries in which they operate (Cantwell et al., 2010). Thus, AMNEs often develop deep personal and organizational connections with leading governmental figures and entities (Cuervo-Cazurra, 2006; Darendeli \& Hill, 2016) in an attempt to shape institutional change decisions in developing countries. For example, thirty-nine pharmaceutical companies attempted to pressure the South African government for stricter IP regulations in 2001 (Anderson, 2006). Ramamurti (2005) also notes that during TRIPS negotiations in the Uruguay Round, Pfizer vigorously lobbied for the global adoption of IP protection standards.

These examples show 'how' AMNEs influence institutional change as they ask for stronger IP protection standards and that the relative number of AMNEs within the innovation system impacts the pace and trajectory of this change. It follows that AMNEs are likely to pressure developing country governments for higher IP protection standards. As a result of these pressures, developing country governments may end up raising IP protection standards to attract even more R\&D-intensive AMNEs. Such an action is incentivecompatible, since the local government expects that higher IP protection standards will generate learning and spillover externalities to local firms leading to further capability enhancements (Kumaraswamy et al., 2012). In such a situation, AMNEs are also more likely to oppose any attempt for local interpretations of the TRIPS text and amendments, since the original TRIPS enforcement mechanisms are better suited to their expectations regarding stringency. We hypothesize:

Hypothesis 1: A large presence of AMNEs in developing country innovation systems results in a fast and stringent regulatory adoption of TRIPS.

\section{The Influence of Supranational Organizations on Regulatory Adoption}

Geels (2014) underlines the importance of facilitators during regulatory adoption and institutional change processes. Similarly, neo-institutional theory suggests that supranational organizations, such as the WTO or IMF, can also apply pressures that influence policy decisions of governments (Biermann, 2002) and institutional change (Jandhyala, 2014). These influences and pressures by many supranational organizations, such as IMF or WTO, often follow similar aims that are based on a global business environment perspective formed by the Washington Consensus (Onis \& Senses, 2005) that objectivizes country developments, i.e., 'why' actors influence institutional change. For example, India acceded to pressures for lower import tariffs 
due to a dependency on IMF credits (Bown \& Tovar, 2011). Similarly, Koning, Mertens, \& Roosenboom, 2018) find that IMF dependence was instrumental in countries' adoption of international financial reporting standards.

Supranational organizations, such as IMF, were actively involved in policy decisions in developing countries during their TRIPS implementation (Onis $\&$ Senses, 2005). However, some maintain that they have disproportionately favored some actors such as banks and AMNEs operating in developing countries, sometimes at the expense of domestic firms (Narula, 2003). Moreover, these pressures could even lead to debt crises in countries in need of support (Onis \& Senses, 2005). The key point is that IP protection is an important part of the IMF's agenda during its negotiations with developing countries (Deere, 2008). When countries seek IMF credits, the agency often makes improved IP protection part of the bargaining (Ramamurti, 2005).

Supranational organizations provide indirect support and function as facilitators, by creating the necessary institutional space where actors, such as firms and governments, can connect and engage in negotiations (Geels, 2014; Krug \& Hendrischke, 2007). Thus, their activities are often subtler and less explicit (Lemola, 2002) and serve to moderate the connection between these actors. Based on the characteristics and objectives of supranational organizations, they often connect strongly with AMNEs (Rugman \& D'Cruz, 1997). Hence, we argue that the dependency on supranational organizations, financially or otherwise, influences TRIPS adoption. Accordingly, we suggest that a developing country's dependence on a supranational organization will reinforce AMNEs' pressures for a fast and stringent regulatory adoption of TRIPS. Accordingly, we argue:

Hypothesis 2: A substantial dependency of a developing country on supranational organizations strengthens the influence of AMNEs for a fast and stringent regulatory adoption of TRIPS.

\section{METHODS}

\section{Data and Sample}

We track regulatory adoption in IP protection regulations for 60 developing countries that signed the TRIPS agreement in 1994. As some developing countries began implementation during the negotiation period in 1993 (Taubman et al., 2012), we track developments of each country's innovation system for ratification by the relevant government and enforcement of the agreement from January 1, 1993 to December 31, 2005. We merge these data with the patent data from Harvard Patent Dataverse, which uses patents from the United States Patent and Trademark Office (USPTO), in order to assess the strength of the innovation system. We classify patents that are representative of the pharmaceutical, electronics, computer and software industries by using Hall, Jaffe, and Trajtenberg's (2001) classification. We preselected these four industries as representative of knowledge-intensive industries that are directly and most significantly affected by IP-related regulations, following the procedure pioneered by Delgado et al. (2013). We acknowledge that this focus is restricted to highly innovative industries, but argue that these are the most relevant sectors in the context of IP protection. We use assignee locations to identify the geography of the patent and recognize the time variance by including the year the patent was granted. The dependence to IMF data is extracted from the IMF's database on historical Stand-by Agreements (SBAs). Lastly, we include country-level development indicators from the World Bank. We aggregate all of the variables at country level. Our final sample consists of 780 country-year observations.

\section{Measures}

\section{Dependent variable: TRIPS decisions}

We construct a unique TRIPS adoption index since most of the prior IP indices either report changes in 5 -year periods (Park, 2008), focus on one particular industry (see Liu \& La Croix, 2015) or do not cover all 60 developing countries (Deere, 2008; HamdanLivramento, 2009). We use the TRIPS adoption evaluation documents submitted by each country to identify the changes in IP regulations. We coded these changes for each year capturing developing countries' TRIPS adoption progress and triangulate our assessment with other articles/reports (for details, see Table 1).

Our index captures both time to ratify (fast versus slow) and extent of compliance mechanisms (stringent versus loose), which together act as a proxy capturing the differences in decisions regarding the adoption of higher IP protection standards in developing countries. We argue that the decision to ratify/enact the international agreement is the starting point to full regulatory adoption of TRIPS (Deere, 2008). We rank developing countries based 
Table 1 Operationalization of variables in the models

\begin{tabular}{|c|c|c|}
\hline Variable & Operationalization & Source \\
\hline \multicolumn{3}{|l|}{ Dependent - first stage } \\
\hline Innovation capability & Number of patents & USPTO, Harvard Dataverse \\
\hline Initial IPR strength & IPR score & Park (2008) \\
\hline \multicolumn{3}{|c|}{ Dependent - second stage } \\
\hline \multirow[t]{5}{*}{ TRIPS adoption } & 1: No transition, without amendments & WTO Country Review \\
\hline & 2: Early ratification, without amendments & Documents \& Deere (2008) \\
\hline & 3: Early ratification, with amendments & \\
\hline & 4: Late ratification, without amendments & \\
\hline & 5: Late ratification, with amendments & \\
\hline \multicolumn{3}{|l|}{ Independent } \\
\hline $\begin{array}{l}\text { Proportion of local firm } \\
\text { patents }\end{array}$ & \# patents by local firm assignees/\# of total patents & USPTO, Harvard Dataverse \\
\hline $\begin{array}{l}\text { Proportion of AMNE } \\
\text { patents }\end{array}$ & \# patents by AMNEs assignees/\# of total patents & USPTO, Harvard Dataverse \\
\hline IMF dependency & $\$$ value IMF credits used & World Bank \\
\hline \multicolumn{3}{|l|}{ Controls } \\
\hline GDP per capita & GDP PPP 2005 US Constant, $000 \mathrm{~s}$ & World Bank \\
\hline FDI & $\log (F D I$ Inflows $)$ & World Bank \\
\hline Export value index & $\begin{array}{l}\text { Export values are the current value of exports (f.o.b.) converted to U.S. } \\
\text { dollars and expressed as a percentage of the average for the base period } \\
(2000)\end{array}$ & World Bank \\
\hline Backward citations & $\#$ of references patents received, $000 \mathrm{~s}$ & USPTO, Harvard Dataverse \\
\hline Disease outbreak & \# of disease outbreaks of international concern by year by country & World Health Organization \\
\hline Voice and accountability & $\begin{array}{l}\text { Voice and accountability captures perceptions of the extent to which a } \\
\text { country's citizens are able to participate in selecting their government, as } \\
\text { well as freedom of expression, freedom of association, and a free media }\end{array}$ & $\begin{array}{l}\text { World Bank Governance } \\
\text { Indicators }\end{array}$ \\
\hline Rule of law & $\begin{array}{l}\text { Rule of law captures perceptions of the extent to which agents have } \\
\text { confidence in and abide by the rules of society, and in particular the quality } \\
\text { of contract enforcement, property rights, the police, and the courts, as well } \\
\text { as the likelihood of crime and violence }\end{array}$ & $\begin{array}{l}\text { World Bank Governance } \\
\text { Indicators }\end{array}$ \\
\hline Control of corruption & $\begin{array}{l}\text { Captures perceptions of the extent to which public power is exercised for } \\
\text { private gain, including both petty and grand corruption }\end{array}$ & $\begin{array}{l}\text { World Bank Governance } \\
\text { Indicators }\end{array}$ \\
\hline $\begin{array}{l}\text { Government } \\
\text { effectiveness }\end{array}$ & $\begin{array}{l}\text { Captures perceptions of the quality of public service, civil service (including } \\
\text { degree of its independence from political pressures), policy formulation and } \\
\text { implementation, and the governments' commitment to such policies }\end{array}$ & $\begin{array}{l}\text { World Bank Governance } \\
\text { Indicators }\end{array}$ \\
\hline $\begin{array}{l}\text { Proportion of local } \\
\text { public sector patents }\end{array}$ & $\begin{array}{l}\text { \# patents by local universities and research organizations assignees/\# of } \\
\text { total patents }\end{array}$ & USPTO, Harvard Dataverse \\
\hline $\begin{array}{l}\text { Proportion of foreign } \\
\text { public sector patents }\end{array}$ & $\begin{array}{l}\text { \# patents by foreign universities and research organizations assignees/\# of } \\
\text { total patents }\end{array}$ & USPTO, Harvard Dataverse \\
\hline Proportion of EMNEs & \# patents by EMNE assignees/\# of total patents & USPTO, Harvard Dataverse \\
\hline Proportion of individuals & \# patents by local individual assignees/\# of total patents & USPTO, Harvard Dataverse \\
\hline
\end{tabular}

on the year they ratified TRIPS, when these standards officially become part of the countries' national legislation (see Table 2 ).

TRIPS allowed developing countries to implement different provisions within their own legal traditions (Deere, 2008), which we classify in this article as amendments. For usage of such flexibilities, we examined the WTO criteria for preliminary injunction. Under TRIPS Article 50.1, a preliminary injunction is interpreted to mean that the courts of WTO members must have the authority to order 'prompt and effective provisional measures' to prevent infringements from occurring and 'preserve evidence relevant to the alleged infringements' (Liu \& La Croix, 2015, p. 210). We also looked for the words 'local,' 'national,' 'regional,' and 'drafted' in order to capture whether the developing country made local interpretations of the original TRIPS text or introduced amendments to the provisions suggested by TRIPS. 
Table 2 TRIPS adoption decision(s) and regulatory adoption of institutional change. Source: Deere (2008) and WTO (1999, 2000, 2004)

\begin{tabular}{|c|c|c|c|c|}
\hline $\begin{array}{l}\text { TRIPS } \\
\text { score }\end{array}$ & $\begin{array}{l}\text { TRIPS adoption decision } \\
\text { (transition, } \\
\text { amendments) }\end{array}$ & $\begin{array}{l}\text { Year of } \\
\text { ratification }^{1}\end{array}$ & $\begin{array}{l}\text { Enforcement } \\
\text { mechanisms }{ }^{2} \text { at } \\
2001 \text { review }\end{array}$ & Countries \\
\hline 1 & $\begin{array}{l}\text { No transition, without } \\
\text { amendments }\end{array}$ & $<1998$ & No & $\begin{array}{l}\text { Argentina, Barbados, Belize, Botswana, Brazil, Colombia, } \\
\text { Cyprus, Indonesia, South Korea, Malaysia, Mexico, } \\
\text { Nicaragua, Trinidad \& Tobago, Turkey }\end{array}$ \\
\hline 2 & $\begin{array}{l}\text { Early ratification, } \\
\text { without amendments }\end{array}$ & $>1998<2001$ & No & $\begin{array}{l}\text { Bahrain, Bolivia, Cameroon, Cote d'Ivoire, Dominica, El } \\
\text { Salvador, Gabon, Grenada, Pakistan, Tunisia }\end{array}$ \\
\hline 3 & $\begin{array}{l}\text { Early ratification, with } \\
\text { amendments }\end{array}$ & $>1998<2001$ & Yes & Estonia, Philippines, Singapore, Uruguay, Venezuela \\
\hline 4 & $\begin{array}{l}\text { Late ratification, } \\
\text { without amendments }\end{array}$ & $>2001 \leq 2005$ & No & $\begin{array}{l}\text { Brunei, Chile, Costa Rica, Egypt, Ghana, Guatemala, } \\
\text { Guyana, Honduras, Jamaica, Kenya, Kuwait, Macau, } \\
\text { Malta, Mauritius, Morocco, Namibia, Nigeria, Papua New } \\
\text { Guinea, Paraguay, Peru, Saint Lucia, Sri Lanka, Surinam, } \\
\text { Thailand, United Arab Emirates, Zimbabwe }\end{array}$ \\
\hline 5 & $\begin{array}{l}\text { Late ratification, with } \\
\text { amendments }\end{array}$ & $>2001 \leq 2005$ & Yes & China, Hong Kong, India, Israel, Poland \\
\hline
\end{tabular}

1 Ratifications between 1995 and 1998 are early ratifications; ratifications from 1999 to 2005 are late ratifications. We determined these ratification phases based on the review schedule of developing countries by the WTO (late 2001/early 2002 and last official review dated late 2004 . The original legislation review documents were submitted by the developing countries to WTO in 1999, 2000 and 2004.

2 See also Brandl et al. (2016) and TRIPS Article 50.1'a preliminary injunction is interpreted to mean that the courts of WTO members must have the authority to order "prompt and effective provisional measures" to prevent infringements from occurring and preserve evidence relevant to the alleged infringements' (Liu \& La Croix, 2015, p. 210).

Accordingly, our final measure is an ordinal variable that ranks developing countries' TRIPS adoption decision on a scale from 1 to 5 (see Table 2 and also Tables 8 and 9 in the Appendix). With this ranking, we followed our earlier outlined argument that amendments are time consuming, costly, and loosen the original provisions, so that ratifications without amendments are implemented faster and are more stringent. We created a codebook and a coding scheme for assigning the appropriate ranking values to the countries in our sample. Two of the authors coded the countries, and the results had strong inter-coder reliability. We crosschecked our coding with the TRIPS indices developed by Deere (2008) and Hamdan-Livramento (2009) for available countries.

\section{Independent variables: percentage of country patents held by local firms and AMNEs}

We manually parsed the assignee information listed in each patent document to identify if a patent is owned by a local firm, an AMNE, a developing/ emerging country MNE (EMNE), a local public sector organization, a foreign public sector organization, or an individual, following Li et al. (2014). Our final measures are the normalized share of local firms and of AMNEs in the country's patent output. We use local firms as the baseline in our models.

\section{Interaction variable: assignee percentage(S) * dependence to IMF}

We operationalize the dependence on supranational organizations by focusing on the IMF. We measure the main effect of dependence by looking at whether the developing country used IMF credits in the relevant period, i.e., if it has an ongoing stand-by agreement (SBA) with the Fund. We use the extent to which the SBA has been exercised, as a measure of the country's dependency on the IMF. We then multiply, first, local firm, and then AMNE percentage share of the country's patent output with the country's dependence on the IMF to generate our interaction variables.

\section{Control variables}

We use a number of other control variables at the country level as well as patent level. Our countrylevel controls include GDP per capita, disease outbreak indicator, control of corruption, political stability and absence of violence, voice and accountability, regulatory quality, government effectiveness, rule of law, and measures for patents from EMNEs, local and foreign universities and public research institutions within the local innovation systems. Since changes in technologies, countries, and other external exogenous factors can affect the innovative capabilities, assignee 
proportions, and TRIPS adoption decisions, we also include year fixed effects to our patent estimation and TRIPS models.

\section{Estimation}

We use a two-step mixed instrumental variable estimation approach. This accounts for possible endogeneity problems related to developing countries' innovation output quality as well as the initial IP protection levels before TRIPS. First, a country's IP policy decisions can be spuriously related to its innovative capabilities and its IP regime (Qian, 2007). Therefore, we needed to control for local innovation capabilities. We follow the long tradition in innovation and technology management research by using patent stocks as a reflection of the country's innovation capabilities (see Jaffe, Trajtenberg \& Henderson, 1993; Awate et al., 2012).

However, we also acknowledge that the patent stock to identify innovation capabilities in a country raises issues concerning the economic value of patents (Hall et al., 2001). The patent count is likely to be endogenously determined by a number of underlying features that relate to the strength of the country's innovation system and the extent of its R\&D development (Acs, Anselin \& Varga, 2002). Therefore, we regress the country's patent output on other innovation capability related factors, such as the number of scientific journal articles published by authors from the focal country, the average number of subclasses, eigenvector centrality of the patents from the focal developing country, and the number of total inventors on patents. We use these estimates as controls for the country's innovation capabilities in the second step regression.

Second, the level of initial IP protection strength in 1999 can affect local firms and AMNEs patenting. It can also impact the extent of IMF extent involvement and subsequent IP protection decisions. Thus, we collected the initial IP protection strength data in 1995 using Park's (2008) IP rights (IPR) Index. Park's index is one of the most comprehensive indices of different countries' IPR levels. The index is a continuous measure, ranking countries' IP protection strengths within a range from 1 to 5,5 being the strongest. The Park IPR Index is calculated for 5-year periods. We followed a similar approach in order to account for endogeneity related to the initial IP protection strength in these countries. Using a number of controls, we first ran a regression that explains the 1995 IPR score for these countries. Then, we used the estimates of this regression as instruments along with the innovation capability instrument in the second stage regression where we test our model to assess the effect of our hypothesized variables on developing countries' TRIPS decisions.

For the second stage, we use ordered Probit estimation through a 'conditional mixed process' (CMP) estimator in Stata 12. This methodology controls for the endogeneity and enables us to use instruments in estimating a model with ordered ordinal outcomes (Roodman, 2011). To check for normality, we performed log transformations on certain variables. We tested for multicollinearity, confirming that VIF levels are below 10.

\section{RESULTS}

Table 3 presents descriptive statistics, showing that the independent variables exhibit considerable variance, making them statistically good explanatory variables. As can be seen in the correlations in Table 4, variables representing the different institutional environments have high and significant correlations among them. Interestingly, the number of patents is not strongly correlated with either GDP per capita or TRIPS decisions. (The first stage regression results estimating the effects of local innovation capabilities and initial IP protection levels are presented in Appendix Tables 6 and 7). All of the variables except the geographical dispersion of patents are significant.

The estimates of our main models are presented in Table 5. Model 1 is the baseline model and shows that domestic firms in developing countries prefer a slow transition to full TRIPS compliance. This is evidenced by the positive and significant effect of the proportion of local firms on slower/less stringent TRIPS adoption. Results also indicate that developing countries with highly stringent IP protection levels before TRIPS, higher GDP, and higher FDI inflows were less likely to choose a slower and less stringent transition. Developing countries with higher innovative capabilities or with less institutional voids are more likely apply a faster transition and more stringent enforcement of TRIPS. Another interesting secondary finding relates to the effect of EMNEs. It appears that EMNEs share the same agenda as local firms in terms of preferring slower and less stringent TRIPS adoption.

Model 2 tests Hypothesis 1. The results indicate that there is a negative and significant effect $(p<0.5)$ of the AMNE share of countries' innovation systems on the likelihood of a slower 
Table 3 Descriptive statistics

\begin{tabular}{|c|c|c|c|c|c|}
\hline Variables & Obs & Mean & SD & Min & Max \\
\hline TRIPS adoption & 780 & 2.314103 & 1.735399 & 0 & 5 \\
\hline Patent output & 780 & 239.0692 & 1286.162 & 0 & 18,368 \\
\hline Initial IPR2 & 780 & 0.278205 & 0.448403 & 0 & 1 \\
\hline GDP per capita & 763 & 6529.717 & 8648.529 & 0.472431 & $47,081.2$ \\
\hline FDI & 693 & 19.89315 & 2.182108 & 9.21034 & 25.43469 \\
\hline Backward citations & 710 & 2834.49 & $14,751.6$ & 0 & 219,570 \\
\hline \# of disease outbreaks & 600 & 0.193333 & 0.503035 & 0 & 3 \\
\hline Voice and accountability & 600 & 3.804501 & 0.536443 & 1.570217 & 4.535491 \\
\hline Rule of law & 600 & 3.754088 & 0.659154 & -0.04402 & 4.561153 \\
\hline Export value index & 769 & 4.634925 & 0.756772 & 3.33128 & 10.1342 \\
\hline Control of corruption & 599 & 3.789285 & 0.704759 & 0.380773 & 4.590428 \\
\hline Proportion of domestic public sector ${ }^{1}$ patents & 703 & 0.095849 & 0.239313 & 0 & 1 \\
\hline Proportion of foreign public sector ${ }^{1}$ patents & 703 & 0.043418 & 0.150539 & 0 & 1 \\
\hline Proportion of EMNE patents & 703 & 0.010834 & 0.047053 & 0 & 0.571429 \\
\hline Proportion of local firm patents & 703 & 0.092677 & 0.193214 & 0 & 1 \\
\hline Proportion of AMNE patents & 752 & 0.312238 & 0.380567 & 0 & 1 \\
\hline IMF dependency & 708 & $2.21 \mathrm{E}+08$ & $1.38 \mathrm{E}+09$ & 0 & $1.77 \mathrm{E}+10$ \\
\hline IMF dependency * proportion of local firm patents & 683 & $1.24 \mathrm{E}+08$ & $8.25 \mathrm{E}+08$ & 0 & $1.04 \mathrm{E}+10$ \\
\hline IMF dependency * proportion of AMNE patents & 641 & $4.17 \mathrm{E}+07$ & $3.39 \mathrm{E}+08$ & 0 & $5.62 \mathrm{E}+09$ \\
\hline
\end{tabular}

${ }^{1}$ PUBLIC sector $=$ universities and research organizations.

transition to TRIPS. The more significant the presence of AMNEs in a country's innovation system, the faster and more stringent is TRIPS adoption.

Model 3 tests Hypothesis 2 and suggests that the coefficient of the cross-term between AMNEs' share of the country's innovation system and the county's dependency on the IMF is negative and significant $(p<0.05)$. This indicates that IMF dependence reinforces the effect of AMNE dominance on TRIPS decisions, pushing for even faster and more stringent TRIPS compliance, supporting H2. Additionally, we tested for a moderating effect of IMF dependence on the influence of domestic firms on the transition to full TRIPS compliance. These results are displayed in Model 3 as well. As can be seen, IMF dependency has no reinforcing effect on the influence of local firms' share within a country's innovation system on the regulatory adoption of TRIPS.

The economic significance of AMNEs in the domestic innovation system can be interpreted as follows. A one-unit increase in the proportion of patents held by local firms, given that other variables are held constant, will result in 0.39-unit increase in the ordered log-odds of ratifying TRIPS late or introducing amendments. Similarly, a oneunit increase in the proportion of AMNE patents in the local innovation system will result in 0.12 unit decrease in the ordered log-odds of ratifying TRIPS late or introducing amendments. Moreover, the economic effect of IMF dependence seems minimal but important. If developing countries dependency on IMF increases by $\$ 1$ billion, the log-likelihood of a faster and more stringent TRIPS adoption increases by $8.4 \%$. We present a visual representation of the interaction in Figure 2.

In order to better interpret substantive and practical significance of our results, we performed marginal effect analyses to measure the effect on the conditional mean of $y$ of a change in each of the relevant regressors (Long \& Freese, 2006). We ran the marginal test analysis after the cmp code is entered to STATA, allowing for margins to be calculated after ordered probit estimations.

We performed the marginal effect analysis for TRIPS decision 1 (see Appendix Figures 3 to 6). Increasing the composition of innovating AMNEs by $1 \%$, increases the probability that TRIPS decision 1 is chosen by $4 \%$. Conversely, increasing composition of local firms by $1 \%$, increases the probability that the TRIPS decision 1 is not chosen by $13 \%$ $(p<0.01)$. For TRIPS decision 2 , the marginal effects for local firms were not significant, but there is a weak marginal effect for AMNEs $(p<0.1)$. This result relates to our argument that most countries that chose to follow TRIPS decision 2 have an underdeveloped innovation system compared to countries in other decision groups. Hence, the effect of local firms is minimal and spurious for an early ratification without amendments. We 


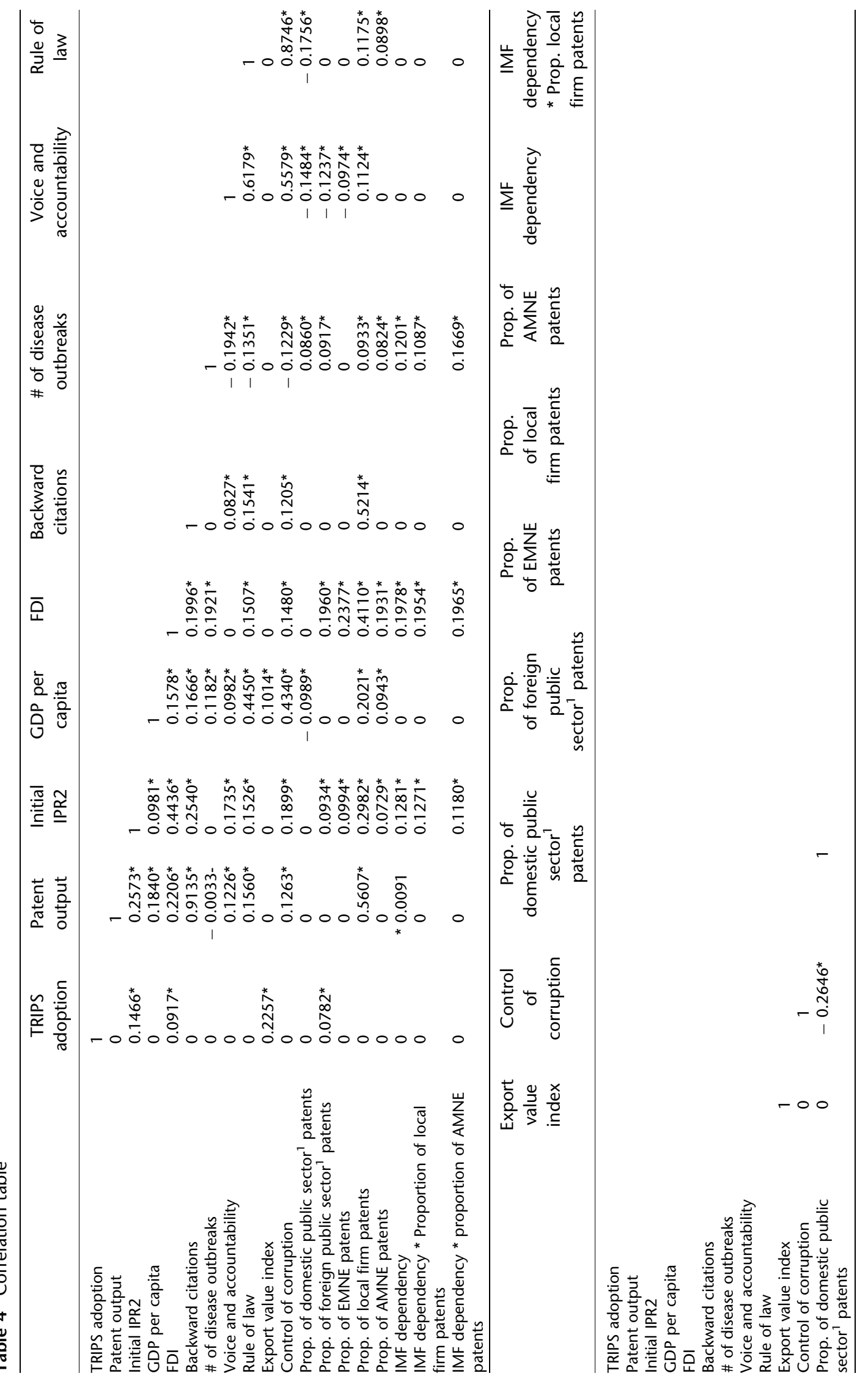




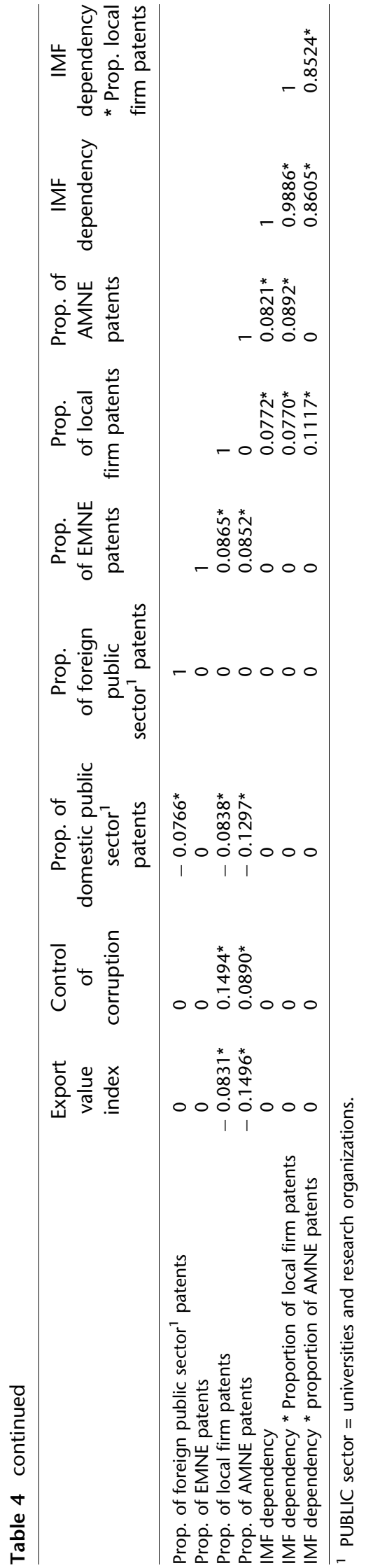

could not find a statistically significant marginal difference between proportions of local firms in contrast to AMNEs for TRIPS decision 3, due to a paucity of degrees of freedom. We only found a weak marginal effect of AMNEs $(p<0.1)$ for not choosing TRIPS decision 4 , increasing the probability of choosing this decision by only $1 \%$. For TRIPS decision 5, both local firms and AMNEs had significant $(p<0.05)$ marginal effects, in counter direction of decision 1 . Increasing local firm composition by $1 \%$ increases the probability that this decision is chosen by $12 \%$ and composition of AMNEs by $1 \%$ increases the probability that this decision is not chosen by $4 \%$.

\section{DISCUSSION AND CONCLUSION}

We studied the influence of AMNEs and supranational organizations on the regulatory adoption of IP protection standards by developing countries to adapt to the levels prevalent in advanced countries. We build upon the arguments of 'why' and 'how' actors adapt to and shape institutions (Cantwell et al., 2010; Kostova et al., 2008), based on their interests and power dynamics (Oliver, 1992). We find empirical support for the position that in the context of TRIPS, firms indeed influence governments' decisions regarding formal institutions through political strategies, especially in the presence of institutional voids (Bonardi et al., 2005; Suchman, 1995). 'When' these actors influence, the change is strongly dependent on the 'why' and 'how' considerations. We find that domestic firms in developing countries prefer a slow and less stringent transition to higher IP standards, as the firms lag behind in terms of innovation capabilities (Ramamurti, 2005). An important basis of survival for these firms is imitating the products and processes of their AMNE competitors (Samuelson \& Scotchmer, 2002), activities that are far easier within a regime of weak IP protection. Thus, the larger the proportion of domestic firms in the domestic innovation system, the slower and less stringent is the transition to full TRIPS compliance.

In contrast, we find that the higher the proportion of AMNEs in a developing country's innovation system, the faster and more stringent its TRIPS adoption. AMNEs involve themselves in local environments to pressure domestic governments in order to reduce the transaction costs of their local operations (Williamson, 1979), and it has long been known that internalization is the efficient form of 
Table 5 TRIPS adoption - ordered probit estimates

\begin{tabular}{|c|c|c|c|}
\hline $\begin{array}{l}\text { Dependent variable } \\
\text { TRIPS adoption }\end{array}$ & $\begin{array}{l}\text { Model (1) } \\
\text { Slow adoption with/out } \\
\text { amendments }\end{array}$ & $\begin{array}{l}\text { Model (2) } \\
\text { Slow adoption with/out } \\
\text { amendments }\end{array}$ & $\begin{array}{l}\text { Model (3) } \\
\text { Slow adoption with/out } \\
\text { amendments }\end{array}$ \\
\hline Controls: & $0.00055^{\star * *}$ & $0.00056^{* * *}$ & $0.00061^{* * *}$ \\
\hline Patent output $^{1}$ & $(5.25)$ & $(5.54)$ & $(6.98)$ \\
\hline Initial IPR ${ }^{2}$ & $\begin{array}{l}-0.705^{\star * *} \\
(-4.17)\end{array}$ & $\begin{array}{l}-0.687^{* * *} \\
(-4.77)\end{array}$ & $\begin{array}{l}-0.609 * * * \\
(-4.93)\end{array}$ \\
\hline GDP per capita & $\begin{array}{l}-0.0250^{* * *} \\
(-5.41)\end{array}$ & $\begin{array}{l}-0.0249 * * * \\
(-5.90)\end{array}$ & $\begin{array}{l}-0.0283^{* \star *} \\
(-7.14)\end{array}$ \\
\hline FDI & $\begin{array}{l}-0.0430 * * \\
(-3.05)\end{array}$ & $\begin{array}{l}-0.0349^{\star} \\
(-2.55)\end{array}$ & $\begin{array}{l}-0.0193 \\
(-1.51)\end{array}$ \\
\hline Export value index & $\begin{array}{l}-0.0252 \\
(-0.38)\end{array}$ & $\begin{array}{l}-0.0446 \\
(-0.67)\end{array}$ & $\begin{array}{l}-0.0689 \\
(-1.08)\end{array}$ \\
\hline Backward citations & $\begin{array}{l}0.0110+ \\
(1.72)\end{array}$ & $\begin{array}{l}0.011+ \\
(1.75)\end{array}$ & $\begin{array}{l}0.013+ \\
(1.96)\end{array}$ \\
\hline \# of disease outbreaks & $\begin{array}{l}0.0130 \\
(0.30)\end{array}$ & $\begin{array}{l}0.0141 \\
(0.35)\end{array}$ & $\begin{array}{l}0.00624 \\
(0.17)\end{array}$ \\
\hline Voice and accountability & $\begin{array}{l}-0.0764 \\
(-1.17)\end{array}$ & $\begin{array}{l}-0.0531 \\
(-0.88)\end{array}$ & $\begin{array}{l}-0.0368 \\
(-0.66)\end{array}$ \\
\hline Rule of law & $\begin{array}{l}0.178^{*} \\
(2.34)\end{array}$ & $\begin{array}{l}0.172^{*} \\
(2.38)\end{array}$ & $\begin{array}{l}0.166^{\star} \\
(2.42)\end{array}$ \\
\hline Control of corruption & $\begin{array}{l}-0.0884 \\
(-1.24)\end{array}$ & $\begin{array}{l}-0.0948 \\
(-1.39)\end{array}$ & $\begin{array}{l}-0.0734 \\
(-1.14)\end{array}$ \\
\hline $\begin{array}{l}\text { Proportion of domestic public sector } \\
\text { patents }\end{array}$ & $\begin{array}{l}0.297 \\
(0.24)\end{array}$ & $\begin{array}{l}-0.0230 \\
(0.19)\end{array}$ & $\begin{array}{l}-0.0535 \\
(-0.52)\end{array}$ \\
\hline $\begin{array}{l}\text { Proportion of foreign public sector }{ }^{3} \\
\text { patents }\end{array}$ & $\begin{array}{l}0.0296 \\
(0.28)\end{array}$ & $\begin{array}{l}-0.0112 \\
(-0.11)\end{array}$ & $\begin{array}{l}0.0417 \\
(0.44)\end{array}$ \\
\hline Proportion of EMNE patents & $\begin{array}{l}0.0355^{*} \\
(2.20)\end{array}$ & $\begin{array}{l}0.0324^{*} \\
(2.20)\end{array}$ & $\begin{array}{l}0.0204+ \\
(1.65)\end{array}$ \\
\hline Independent variables: & & & \\
\hline Proportion of local firm patents & $\begin{array}{l}0.416^{*} \\
(2.28)\end{array}$ & $\begin{array}{l}0.377^{*} \\
(2.23)\end{array}$ & $\begin{array}{l}0.352^{*} \\
(2.10)\end{array}$ \\
\hline Proportion of AMNE patents $(\mathrm{H} 1)^{4}$ & & $\begin{array}{l}-0.118^{*} \\
(-2.15)\end{array}$ & $\begin{array}{l}-0.114^{*} \\
(-2.25)\end{array}$ \\
\hline IMF dependency & & & $\begin{array}{l}0.00036^{*} \\
(2.14)\end{array}$ \\
\hline IMF dependency * proportion of local & & & 0.000002 \\
\hline firm patents & & & $(0.01)$ \\
\hline $\begin{array}{l}\text { IMF dependency * proportion of AMNE } \\
\text { patents }(\mathrm{H} 2)^{4}\end{array}$ & & & $\begin{array}{l}-0.00084^{* *} \\
(-2.55)\end{array}$ \\
\hline Year fixed effects & Yes & Yes & Yes \\
\hline$N$ & 705 & 705 & 705 \\
\hline
\end{tabular}

Direct effects of local firm and AMNE proportion of country patents as well as the indirect effect of IMF dependency.

1,2 Instrumented by estimates from the 1 st step regression, $t$ statistics in parentheses; ${ }^{3}$ public sector $=$ universities and research organizations, ${ }^{\star} p<0.05,{ }^{\star \star} p<0.01,{ }^{* \star *} p<0.001 ;{ }^{4}$ The dependent variable is 'slow and less stringent TRIPS adoption,' whereas the hypotheses were stated in terms of 'fast and stringent adoption.' Hence, the negative signs indicate support for the hypotheses.

organization for knowledge-intensive activities (Buckley \& Casson, 1976). Interestingly, our findings show that the presence of AMNEs in a developing country helps the country to develop its local innovation system and positively influences its catch-up process to global institutional environment standards. This is an interesting finding considering that AMNEs also could benefit from low IP protection standards (Acemoglu \& Robinson, 2000).
Their impact on domestic innovation systems relates to extensive discussions in the academic and public environment on the implications of MNE activities in the global business environment.

Moreover, the benefits for individual firms might be significantly different to the benefits for the innovation system of the country as a whole, in the long and short terms. For example, while in the short term some firms, such as domestic firms, may 


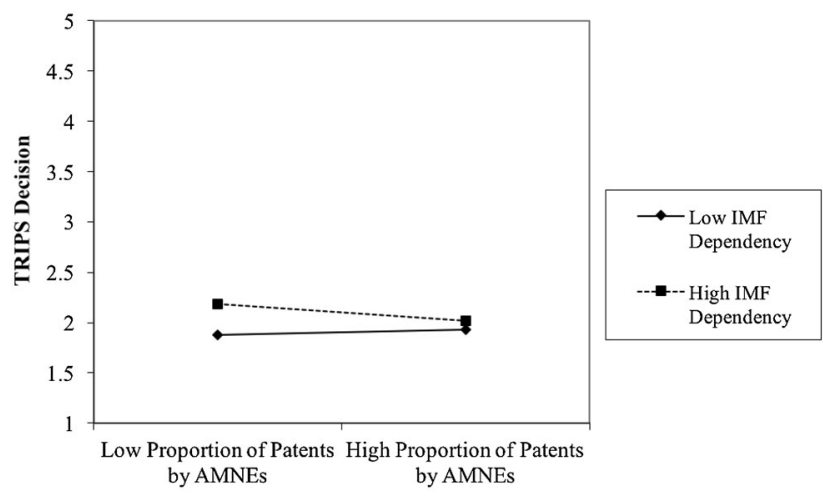

Figure 2 Interaction between dependency on IMF credit and AMNE composition on rate of TRIPS adoption.

lose, the population of firms in the innovation system might benefit. As found, domestic firms initially prefer loose IP protection standards and their preference only slowly changes over time (Kumaraswamy et al., 2012). Kumaraswamy et al. (2012) find that weaker firms that cannot develop 'catch-up processes' always remain hostile toward stronger IP regulations or can no longer compete and exit the market. As the stronger surviving firms become more sophisticated and advanced, they eventually recognize the benefits of stringent IP regimes, especially as they begin creating their own IP. This changing support of stringent IP protection can, for example, be seen in the Indian pharmaceutical industry where leading firms took time to recognize the benefits of TRIPS (Brandl, Mudambi \& Scalera, 2015).

We also find that supranational organizations often (intentionally or unintentionally) reinforce the efforts of AMNEs to promote accession to international IPR standards (Rugman \& D'Cruz, 1997). We conclude that external pressures and facilitators that aim to protect IP protection standards tend to complement one another, a finding that resonates the extant literature (Krug \& Hendrischke, 2007; Deere, 2008). This result stands in contrast to a line of studies that argue for a jurisdictional limitation of supranational agreements, as individual countries are likely to pursue their distinctive national interests (e.g., Scholte, 2005).

\section{Implications and Future Research Opportunities}

Our research has significant implications for theory and practice. First, early studies on institutional change often studied advanced countries where institutional environments are already established. However, it is more difficult to study the nature and adoption of institutional change within these stable environments. Institutions in developing countries are in a state of transition and flux and the process of formalization is in progress (Peng et al., 2017). Moreover, transition trajectories and change processes vary across these contexts and thus we are able to observe considerable diversity. We are able to estimate results for five different TRIPS transition trajectories. Our results are especially significant in the more drastic trajectories, i.e., TRIPS decisions 1 and 5, indicating that the extreme cases of domestic innovation system transition are most impacted by external influences.

This perspective also allows for the study of the activities of AMNEs in overcoming institutional voids, thus contributing to an under-researched area (Doh et al., 2017). We are able to analyze the process of developing countries reaching global standards, in our case global IP protection standards, contributing to literature on developing country catch-up (e.g., Awate et al., 2012; Kumaraswamy et al., 2012; Brandl \& Mudambi, 2014). Lessons for managers of firms that are active in innovation systems of developing countries learn that unless AMNEs have a significant stake in local innovation systems, they have no incentive to use their leverage and lobbying powers to speed up the convergence to global institutional standards.

Moreover, we contribute to institutional change theory with further insights into the effects of external factors on change and underlying factors that affect the associated trajectories (McGaughey et al., 2016). We provide detailed and longitudinal analyses of the influence of actors on regulatory adoptions in regimes with institutional plasticity, which is novel and provides policymakers in developing countries with insights into the forces within their institutional environments. Our results can help in the development of rules and regulations that are conducive to the catch-up process by enhancing the innovative performance of the domestic innovation system.

These findings and their implications suggest a variety of future research opportunities. First, we theorize that the mere presence of AMNEs in the local innovation system influences institutional changes. We do not study the nature of this influence; such a focus requires data on the involvement of the firms in the local political system, not merely in the local innovation system.

Further, we use the IMF as an appropriate representation for the pressure of supranational organizations on developing countries. We expect equivalent results, especially for other 
organizations following the Washington Consensus, which could be tested. We only investigate the effect of the varying decisions of developing countries in terms of pace of regulatory convergence to global institutional standards and focus on the of TRIPS compliance cycles. However, TRIPS is a complex agreement and each country has different contexts and challenges in the ratification processes.

Lastly, we endorse the position of McGaughey, Kumaraswamy and Liesch (2016) that future research should emphasize informal institutions. We study formal institutions, but acknowledge that a focus on informal institutions would also highlight the role of a range of other stakeholders, as suggested by Doh et al. (2017) in the context of institutional voids. changes related to the legislation and enforcement

\section{NOTES}

${ }^{1}$ We follow the WTO definition and classification of developing countries (WTO, 2017). This group of countries includes the subgroup of countries that have achieved significant progress in the development process and are often called 'emerging economies.'

${ }^{2}$ Some draw parallels between the US history of IP abuse in the nineteenth century and today's developing countries (Peng et al., 2017), while others argue that, for example, China has norms and institutions that are so different from those in the West, that it is unlikely to follow the US path (Brander et al., 2017).

${ }^{3} \mathrm{We}$ are aware that there were other flexibilities offered as a part of TRIPS agreement, but they are out of the scope of our article.

${ }^{4}$ We are only interested in flexibilities that are directly related to the level of enforcement of innovation and patents within the scope of the TRIPS agreement and disregard flexibilities related to global or local epidemics, such as HIV/AIDs, avian flu, or leukemia which were also granted but predominantly for least developed countries (Jandhyala, 2014).

\section{REFERENCES}

Abramovitz, M. 1986. Catching up, forging ahead, and falling behind. Journal of Economic History, 46(2): 385-406.

Acemoglu, D., \& Robinson, J. 2000. Political losers as a barrier to economic development. American Economic Review, 90(2): 126-130.

Acs, Z., Anselin, L., \& Varga, A. 2002. Patents and innovation counts as measures of regional production of new knowledge. Research Policy, 31(7): 1069-1085.

Anderson, A. J. 2006. Global pharmaceutical patent law in developing countries - amending TRIPS to promote access for all. Bepress Legal Repository, 1109: 1-48.

Awate, S., Larsen, M. M., \& Mudambi, R. 2012. EMNE catch up strategies in the wind turbine industry: Is there a trade-off between output and innovation capabilities? Global Strategy Journal, 2(3): 205-223.

Baron, D. 1995. Integrated strategy: Market and non-market components. California Management Review, 37(2): 47-65.

Biermann, F. 2002. Institutions for scientific advice: Global environmental assessments and their influence in developing countries. Global Governance, 8(2): 195-219.

Blomström, M., \& Kokko, A. 1998. Multinational corporations and spillovers. Journal of Economic Surveys, 12(3): 247-277.

Bonardi, J. P., Hillman, A. J., \& Keim, G. D. 2005. The attractiveness of political markets: Implications for firm strategy. Academy of Management Review, 30(2): 397-413.

Botoy, I. 2004. From the Paris convention to the TRIPS agreement. Journal of World Intellectual Property, 7(1): 115-130.

Bown, C. P., \& Tovar, P. 2011. Trade liberalization, antidumping, and safeguards: Evidence from India's tariff reform. Journal of Development Economics, 96(1): 115-125.

Brander, J., Cui, V., \& Vertinsky, I. 2017. China and intellectual property rights: A challenge to the rule of law. Journal of International Business Studies, 48(7): 908-921.

Brandl, K., Darendeli, I., Hamilton, R. D., \& Mudambi, R. 2016. The impact of actors and the aspect of time in institutional change processes in a developing country context. Chapter 4. In H. Tuselmann, S. Buzdugan, Q. Cao, D. Freund, \& S. Golesorkhi (Eds.), Impact of international business: Challenges and solutions for policy and practice (pp. 62-78). Basingstoke: Palgrave Macmillan.

Brandl, K., \& Mudambi, R. 2014. EMNEs and catch-up processes: The case of four Indian industries. Chapter 7. In A. Cuervo-Cazurra \& R. Ramamurti (Eds.), Emerging market multinationals: Looking back, looking ahead (pp. 129-152). Cambridge: Cambridge University Press.

Brandl, K., Mudambi, R., \& Scalera, V. G. 2015. The spectacular rise of the Indian pharmaceutical industry. Entrepreneur \& Innovation Exchange. December 4.

Branstetter, L. G. 2001. Are knowledge spillovers international or intranational in scope? Microeconometric evidence from the US and Japan. Journal of International Economics, 53(1): 53-79.

Branstetter, L., Fisman, R., \& Foley, C. F. 2006. Do stronger intellectual property rights increase international technology transfer? Empirical evidence from US firm-level panel data. Quarterly Journal of Economics, 121(1): 321-349.

Buckley, P. J., \& Casson, M. 1976. The future of the multinational enterprise. London: Macmillan.

Cantwell, J., Dunning, J. H., \& Lundan, S. M. 2010. An evolutionary approach to understanding international business activity: The co-evolution of MNEs and the institutional environment. Journal of International Business Studies, 41(4): 567-586.

Cantwell, I., \& Mudambi, R. 2005. MNE competence-creating subsidiary mandates. Strategic Management Journal, 26(12): 1109-1128.

Cantwell, J. A., \& Mudambi, R. 2011. Physical attraction and the geography of knowledge sourcing in multinational enterprises. Global Strategy Journal, 1(3-4): 206-232.

Choudhury, P., \& Khanna, T. 2014. Toward resource independence: Why state-owned entities become multinationals: An empirical study of India's public R\&D laboratories. Journal of International Business Studies, 45(8): 943-960. 
Coriat, B., \& Weinstein, O. 2002. Organizations, firms and institutions in the generation of innovation. Research Policy, 31(2): 273-290.

Cuervo-Cazurra, A. 2006. Who cares about corruption? Journal of International Business Studies, 37(6): 807-822.

Cuervo-Cazurra, A., \& Dau, L. A. 2009. Promarket reforms and firm profitability in developing countries. Academy of Management Journal, 52(6): 1348-1368.

Darendeli, I. S., \& Hill, T. L. 2016. Uncovering the complex relationships between political risk and MNE firm legitimacy: Insights from Libya. Journal of International Business Studies, 47(1): 68-92.

Deere, C. 2008. The implementation game: The TRIPS agreement and the global politics of intellectual property reform in developing countries. Oxford: Oxford University Press.

Delgado, M., Kyle, M., \& McGahan, A. M. 2013. Intellectual property protection and the geography of trade. Journal of Industrial Economics, 61(3): 733-762.

Doh, J., Rodrigues, S., Saka-Helmhout, A., \& Makhija, M. 2017. Special Issue: International business responses to institutional voids. Journal of International Business Studies, 48(3): 293-307.

Fiori, S. 2002. Alternative visions of change in Douglass North's new institutionalism. Journal of Economic Issues, 36(4): 1025-1043.

Geels, F. W. 2014. Re-conceptualising the co-evolution of firmsin-industries and their environments: Developing an interdisciplinary Triple Embeddedness Framework. Research Policy, 43(2): 261-277.

Hall, B. H., Jaffe, A. B., \& Trajtenberg, M. 2001. The NBER patent citation data file: Lessons, insights and methodological tools (no. w8498). National Bureau of Economic Research.

Hamdan-Livramento, I. M. 2009. How compliant are developing countries with their TRIPS obligations? CEMI-WORKINGPAPER-2009-001.

Helpman, E. 1993. Innovation, imitation, and intellectual property rights. Econometrica, 61: 1247-1280.

Hennart, J. F. 2009. Down with MNE-centric theories! Market entry and expansion as the bundling of MNE and local assets. Journal of International Business Studies, 40(9): 1432-1454.

Hillman, A. J., \& Hitt, M. A. 1999. Corporate political strategy formulation: A model of approach, participation, and strategy decisions. Academy of Management Review, 24(4): 825-842.

Hillman, A. J., Keim, G. D., \& Schuler, D. 2004. Corporate political activity: A review and research agenda. Journal of Management, 30(6): 837-857.

Hoskisson, R. E., Eden, L., Lau, C. M., \& Wright, M. 2000. Strategy in emerging economies. Academy of Management Journal, 43(3): 249-267.

Jaffe, A. B., Trajtenberg, M., \& Henderson, R. 1993. Geographic localization of knowledge spillovers as evidenced by patent citations. Quarterly Journal of Economics, 108(3): 577-598.

Jandhyala, S. 2014. International and domestic dynamics of intellectual property protection. Journal of World Business, 50(2): 284-293.

Johanson, J., \& Vahlne, J.-E. 2009. The Uppsala process model revisited: From liability of foreignness to liability of outsidership. Journal of International Business Studies, 40(9): 1411-1431.

Kano, L., \& Verbeke, A. 2015. The three faces of bounded reliability. California Management Review, 58(1): 97-122.

Khanna, T., \& Palepu, K. 1997. Why focused strategies may be wrong for emerging markets. Harvard Business Review, 75(4): 41-48.

Koning, M., Mertens, G., \& Roosenboom, P. 2018. Drivers of institutional change around the world: The case of IFRS. Journal of International Business Studies, 49(3): 249-271.

Kostova, T., Roth, K., \& Dacin, M. T. 2008. Institutional theory in the study of multinational corporations: $A$ critique and new directions. Academy of Management Review, 33(4): 994-1006.

Krug, B., \& Hendrischke, H. J. (Eds.). 2007. The Chinese economy in the 21st century: Enterprise and business behavior. Cheltenham: Edward Elgar Publishing.
Kumaraswamy, A., Mudambi, R., Saranga, H., \& Tripathy, A. 2012. Catch-up strategies in the Indian auto components industry: Domestic firms' responses to market liberalization. Journal of International Business Studies, 43(4): 368-395.

Lemola, T. 2002. Convergence of national science and technology policies: The case of Finland. Research Policy, 31(8): 1481-1490.

$\mathrm{Li}, \mathrm{X} .2008$. The impact of higher standards in patent protection for pharmaceutical industries under the TRIPS Agreement: A comparative study of China and India. World Economy, 31(10): 1367-1382.

Li, Q., \& Resnick, A. 2003. Reversal of fortunes: Democratic institutions and foreign direct investment inflows to developing countries. International Organization, 57(1): 175-211.

Li, G.-C., Lai, R., D'Amour, A., Doolin, D., Sun, Y., Torvik, V., Yu, A., \& Fleming, L. 2014. Disambiguation and co-authorship networks of the US patent inventor database (1975-2010). Research Policy, 43(6): 941-955.

Liesch, P. W., Welch, L. S., \& Buckley, P. J. 2011. Risk and uncertainty in internationalisation and international entrepreneurship studies. Management International Review, 51(6): 851-873.

Liu, M., \& La Croix, S. 2015. A cross-country index of intellectual property rights in pharmaceutical inventions. Research Policy, 44(1): 206-216.

Long, J. S., \& Freese, J. 2006. Regression models for categorical dependent variables using stata. College Station, Texas: Stata Press Publications.

Lybbert, T. J. 2002. On assessing the cost of TRIPS implementation. World Trade Review, 1(3): 309-321.

Marron, D. B., \& Steel, D. G. 2000. Which countries protect intellectual property? The case of software piracy. Economic Inquiry, 38(2): 159-174.

Maskus, K. 2000. Intellectual property in the global economy. Washington, DC: Institute for International Economics.

McCalman, P. 2001. Reaping what you sow: An empirical analysis of international patent harmonization. Journal of International Economics, 55: 161-186.

McGaughey, S. L., Kumaraswamy, A., \& Liesch, P. W. 2016. Institutions, entrepreneurship and co-evolution in international business. Journal of World Business, 51(6): 871-881.

McGaughey, S. L., Liesch, P. W., \& Poulson, D. 2000. An unconventional approach to intellectual property protection: The case of an Australian firm transferring shipbuilding technologies to China. Journal of World Business, 35(1): 1-20.

Motohashi, K. 2005. University-industry collaborations in Japan: The role of new technology-based firms in transforming the National Innovation System. Research Policy, 34(5): 583-594.

Mudambi, R. 1991. Government policy toward MNEs in the presence of foreign exchange scarcity. Eastern Economic Journal, 19(1): 99-108.

Mudambi, R. 1998. International financial management - a review. Journal of Finance, 53(3): 1194-1197.

Mudambi, R. 2008. Location, control and innovation in knowledge intensive industries. Journal of Economic Geography, 8(5): 699-725.

Narula, R. 2003. Globalization and technology: Interdependence, innovation systems and industrial policy. New York: Wiley.

Nelson, R. 1993. National innovation systems: A comparative analysis. Oxford: Oxford University Press.

Nelson, R. R., \& Winter, S. G. 1982. An evolutionary theory of economic change. Boston: Belknap Press of the Harvard University Press.

North, D. C. 1990. Institutions, institutional change and economic performance. Cambridge: Cambridge University Press.

North, D. C. 2005. Understanding the process of economic change. Princeton, NJ: Princeton University Press.

Oliver, C. 1992. The antecedents of deinstitutionalization. Organization Studies, 13(4): 563-588.

Onis, Z., \& Senses, F. 2005. Rethinking the emerging postWashington Consensus. Development and Change, 36(2): 263-290. 
Paraskevopoulou, E. 2012. Non-technological regulatory effects: Implications for innovation and innovation policy. Research Policy, 41(6): 1058-1071.

Park, W. G. 2008. International patent protection: 1960-2005. Research Policy, 7(4): 761-766.

Patriotta, G., Gond, J. P., \& Schultz, F. 2011. Maintaining legitimacy: Controversies, orders of worth, and public justifications. Journal of Management Studies, 48(8): 1804-1836.

Peng, M. W., Ahlstrom, D., Carraher, S., \& Shi, W. 2017. An institution-based view of global IPR history. Journal of International Business Studies, 48(7): 893-907.

Qian, Y. 2007. Do national patent laws stimulate domestic innovation in a global patenting environment? A cross-country analysis of pharmaceutical patent protection, 1978-2002. Review of Economics and Statistics, 89(3): 436-453.

Ramamurti, R. 2005. Global regulatory convergence: The case of intellectual property rights. In R. Grosse (Ed.), International business and government relations in the 21st century (pp. 341-360). Cambridge: Cambridge University Press.

Rodrik, D. 2000. Institutions for high-quality growth: What they are and how to acquire them. Studies in Comparative International Development, 35(3): 3-31.

Roodman, D. 2011. Estimating fully observed recursive mixedprocess models with cmp. Stata Journal, 11(2): 159-206.

Rugman, A., \& D'Cruz, J. 1997. The theory of the flagship firm. European Management Journal, 15(4): 403-412.

Rugman, A. M., \& Verbeke, A. 2000. Multinational enterprises and public policy. In International business (pp. 21-43). London: Palgrave Macmillan.

Samuelson, P., \& Scotchmer, S. 2002. The law and economics of reverse engineering. The Yale Law Journal, 111(7): 1575-1663.

Sanna-Randaccio, F., \& Veugelers, R. 2007. Multinational knowledge spillovers with decentralised R\&D: A game-theoretic approach. Journal of International Business Studies, 38(1): 47-63.

Scholte, J. 2005. Globalization: A critical introduction (2nd ed.). Basingstoke: Palgrave Macmillan.

Scott, W. R. 2013. Institutions and organizations (4th ed.). Thousand Oaks, CA: Sage.
Stigler, G. 1971. The theory of economic regulation. Bell Journal of Economics, 2(1): 3-21.

Suchman, M. C. 1995. Managing legitimacy: Strategic and institutional approaches. Academy of Management Review, 20(3): 571-610.

Taubman, A., Wager, H., \& Watal, J. (Eds.). 2012. A handbook on the WTO TRIPS agreement. Cambridge: Cambridge University Press.

Verbeke, A. 2003. The evolutionary view of the MNE and the future of internalization theory. Journal of International Business Studies, 34(6): 498-504.

Verbeke, A., \& Greidanus, N. J. 2009. The end of the opportunism vs trust debate: Bounded reliability as a new envelope concept in research on MNE governance. Journal of International Business Studies, 40(9): 1417-1495.

Verbeke, A., \& Kano, L. 2016. An internalization theory perspective on the global and regional strategies of multinational enterprises. Journal of World Business, 51(1): 83-92.

Way, L. A., \& Levitsky, S. 2007. Linkage, leverage, and the postcommunist divide. East European Politics and Societies, 21: 48-66.

Williamson, O. E. 1979. Transaction-cost economics: The governance of contractual relations. Journal of Law and Economics, 22(2): 233-261.

Williamson, P. J. 2010. Cost innovation: Preparing for a 'valuefor-money' revolution. Long Range Planning, 43(2): 343-353.

WTO. 2017. Annual Report. Geneva: World Trade Organization

Yang, D., \& Sonmez, M. 2013. Integration and divergence of patent systems across national and international institutions. Journal of World Business, 48(4): 527-538.

Zaheer, S. 1995. Overcoming the liability of foreignness. Academy of Management Journal, 38(2): 341-363.

Zeschky, M., Widenmayer, B., \& Gassmann, O. 2011. Frugal innovation in emerging markets. Research-Technology Management, 54(4): 38-45.

See Tables 6, 7, 8, 9 and Figures 3, 4, 5, 6 .

\section{APPENDIX}

Table 6 Estimating country patent output

Dependent variable: patent output

Strength of local innovation system

Scientific and technical journal articles

$0.0000416^{* * *}$

GDP per capita

(5.81)

$0.777^{\star \star *}$

(6.04)

Geographical dispersion of patents

$(-0.91)$

Total \# of inventors

$0.0000370^{* * *}$

(4.27)

Number of subclasses

$-0.00000570^{\star}$

$(-2.37)$

Year fixed effects

Yes

cons

$t$ statistics in parentheses, ${ }^{*} p<0.05,{ }^{* *} p<0.01,{ }^{* *} p<0.001$ 
Table 7 Estimating initial IPR strength before 1995

Initial IP protection level

Strength of IP protection before TRIPS

GPD pp

0.0729

(1.48)

Regulatory quality

0.00925

Government effectiveness

$-0.000966$

$(-0.17)$

\# of patents

$0.00579^{\star * *}$

(5.03)

cons

$-1.811^{\text {*** }}$

$(-5.26)$

N

587

Table 8 Example identification of transition and amendments for Egypt, Brazil, Turkey, and India. Source: Deere (2008) and original legislation review documents submitted by the developing countries to WTO in 1999, 2000 and 2004

\begin{tabular}{|c|c|c|c|c|c|c|c|c|}
\hline Country & $\begin{array}{l}\text { Year of } \\
\text { review } \\
\text { document }\end{array}$ & $\begin{array}{l}\text { Year of } \\
\text { ratification }\end{array}$ & $\begin{array}{l}\text { 10-year } \\
\text { transition } \\
\text { used }\end{array}$ & $\begin{array}{l}\text { Amendments } \\
\text { of TRIPS text } \\
\text { mentioned }\end{array}$ & $\begin{array}{l}\text { Example of } \\
\text { amendments }\end{array}$ & $\begin{array}{l}\text { Emphasis on } \\
\text { local } \\
\text { enforcement } \\
\text { mechanisms }\end{array}$ & $\begin{array}{l}\text { Year of } \\
\text { enforcement } \\
\text { mechanisms } \\
\text { in law }\end{array}$ & $\begin{array}{l}\text { Pre-TRIPS } \\
\text { IP } \\
\text { protection } \\
\text { level }\end{array}$ \\
\hline Egypt & $\begin{array}{l}2001 \\
2005\end{array}$ & 2002 & $\begin{array}{l}\text { Yes } \\
\text { Yes }\end{array}$ & $\begin{array}{l}\text { No } \\
\text { Some }\end{array}$ & $\begin{array}{l}\text { Other broad } \\
\text { exceptions: 'Any other } \\
\text { acts by third parties, } \\
\text { provided they do not } \\
\text { unreasonably hamper } \\
\text { the normal } \\
\text { exploitation of the } \\
\text { patent' }\end{array}$ & $\begin{array}{l}\text { No } \\
\text { Some }\end{array}$ & $>2001$ & Low \\
\hline Brazil & $\begin{array}{l}2001 \\
2004\end{array}$ & 1996 & & $\begin{array}{l}\text { No } \\
\text { No }\end{array}$ & & $\begin{array}{l}\text { No } \\
\text { No }\end{array}$ & $>1998$ & Low \\
\hline Turkey & $\begin{array}{l}2000 \\
2004\end{array}$ & 1995 & & $\begin{array}{l}\text { No } \\
\text { No }\end{array}$ & & $\begin{array}{l}\text { No } \\
\text { No }\end{array}$ & $>1998$ & Low \\
\hline India & $\begin{array}{l}2001 \\
2005\end{array}$ & 2005 & $\begin{array}{l}\text { Yes } \\
\text { Yes }\end{array}$ & $\begin{array}{l}\text { Yes } \\
\text { Yes }\end{array}$ & & $\begin{array}{l}\text { Yes } \\
\text { Yes }\end{array}$ & 2005 & Low \\
\hline
\end{tabular}

Table 9 Examples of additional TRIPS flexibilities. Source: Deere (2008) and WTO (1999, 2000, 2004)

\begin{tabular}{|c|c|c|c|c|c|}
\hline Example of additional TRIPS flexibilities & $\begin{array}{l}\text { Public } \\
\text { health } \\
\text { issue }\end{array}$ & $\begin{array}{l}\text { Public } \\
\text { research } \\
\text { related }\end{array}$ & $\begin{array}{l}\text { Affects year } \\
\text { of } \\
\text { ratification }\end{array}$ & $\begin{array}{l}\text { Affects } \\
\text { enforcement of } \\
\text { IPR in general }\end{array}$ & $\begin{array}{l}\text { Affects } \\
\text { enforcement of } \\
\text { firm patents }\end{array}$ \\
\hline Exhaustion regime in industrial property & Yes & Yes & No & Yes & No \\
\hline $\begin{array}{l}\text { Exclusion of diagnostic, therapeutic, and surgical methods } \\
\text { from patentability. Article } 27.3 \mathrm{a}\end{array}$ & Yes & Yes & No & No & No \\
\hline $\begin{array}{l}\text { Exclusion of plants, animals, and essentially biological } \\
\text { processes for the production of plants and animals from } \\
\text { patentability. Article } 27.3 \mathrm{~b}\end{array}$ & Yes & Yes & No & No & No \\
\hline Exclusions for new uses of known products & Yes & No & No & Yes & No \\
\hline Bolar exceptions & No & No & No & Yes & No \\
\hline
\end{tabular}




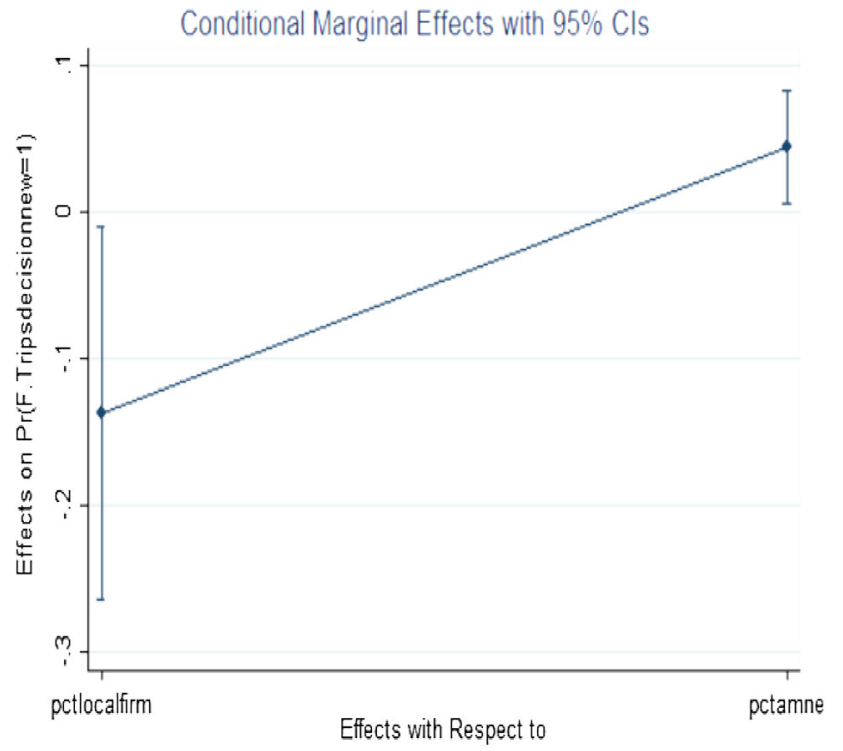

Figure 3 Margin plot TRIPS decision 1.

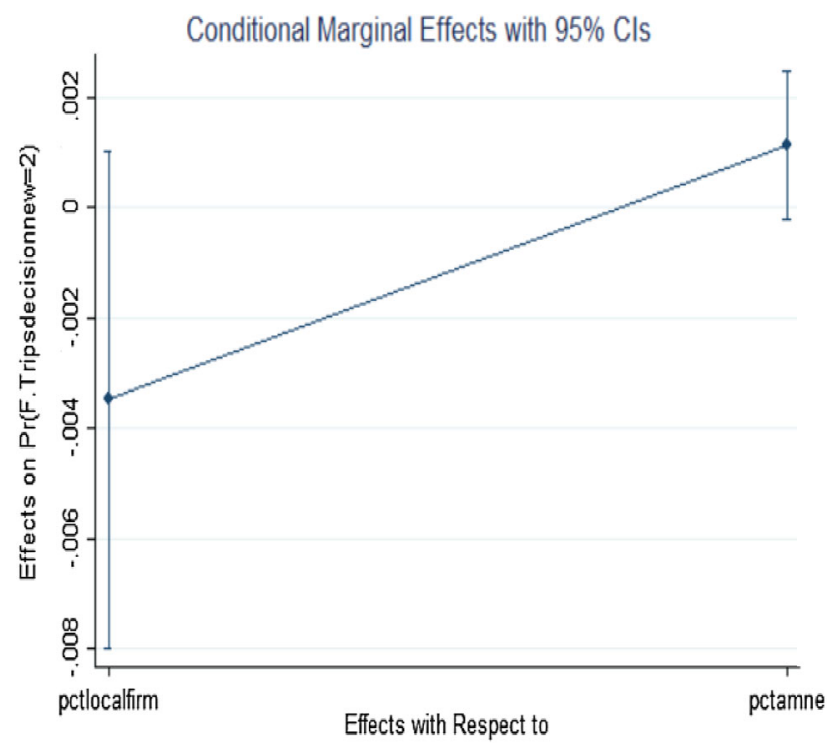

Figure 4 Margin plot TRIPS decision 2.

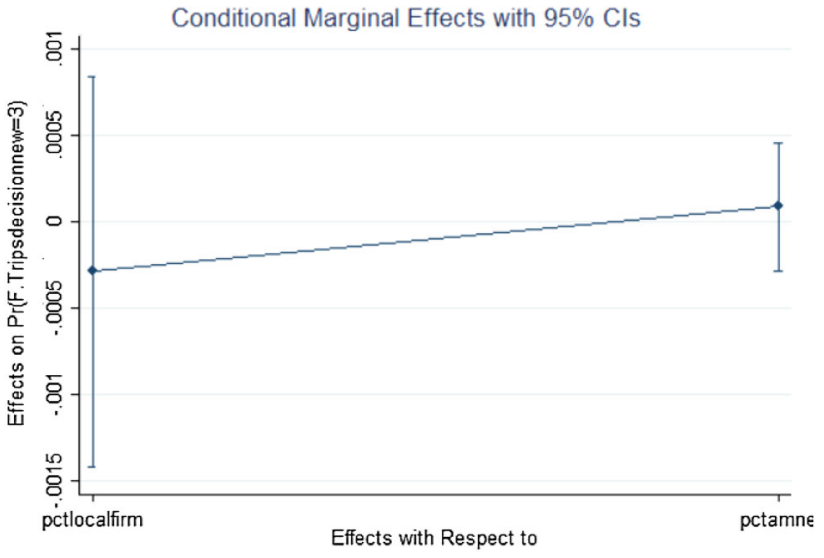

Figure 5 Margin plot TRIPS decision 3.

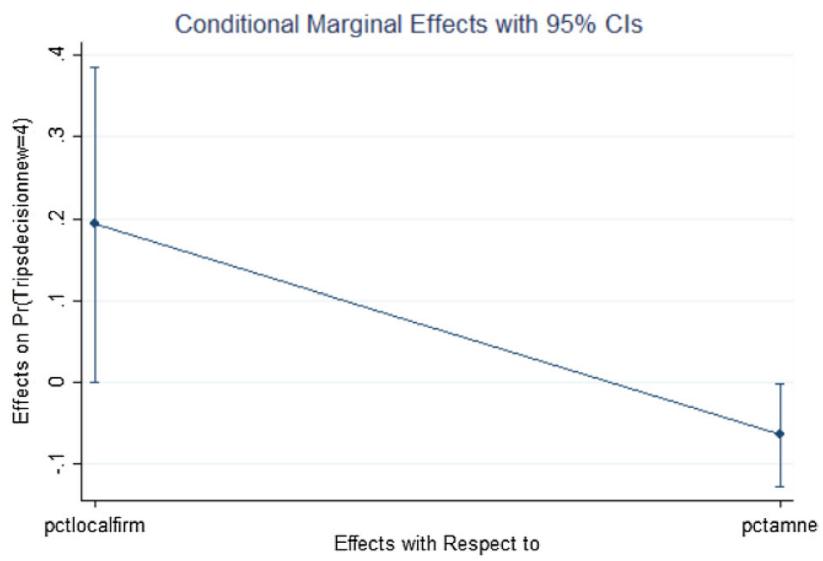

Figure 6 Margin plot TRIPS decision 5. 


\section{ABOUT THE AUTHORS}

Kristin Brandl is an Assistant Professor at the Gustavson School of Business at the University of Victoria. She received her Ph.D. from Copenhagen Business School. Her work has appeared in the International Journal of Operations \& Production Management, the Global Strategy Journal, the International Business Review, and several other international journals.

Izzet Darendeli is an Assistant Professor at the College of Business and Economics at California State University - East Bay. He received his Ph.D. from Temple University. His work has appeared in the Journal of International Business Studies, the Journal of Business Research, and several other outlets.

Ram Mudambi is the Frank M. Speakman Professor of Strategy at the Fox School of Business at Temple
University. He is a Fellow of the Academy of International Business (AIB) as well as of the European International Business Academy (EIBA). He received his Ph.D. from Cornell University. His work has appeared in the Journal of International Business Studies, the Journal of Political Economy, the Journal of Economic Geography, and the Strategic Management Journal among many others.

Open Access This article is distributed under the terms of the Creative Commons Attribution 4.0 International License (http://creativecommons.org/ licenses/by/4.0/), which permits unrestricted use, distribution, and reproduction in any medium, provided you give appropriate credit to the original author(s) and the source, provide a link to the Creative Commons license, and indicate if changes were made. 